\title{
Wolfson Foundation's policy on animals angers other British medical charities
}

London. British medical charities are concerned that a refusal by one foundation to provide grants for experiments involving animals may stimulate the anti-vivisectionist movement and increase the difficulties facing medical researchers who consider such experiments to be essential.

The criticism follows complaints to the Physiological Society by some of its members about guidelines issued to potential grant applicants by the Wolfson Foundation, one of Britain's leading sponsors of university research. These state that the trustees of the foundation "do not normally make grants for ... research involving animals".

There is particular concern about the impact of this restriction on applicants for the foundation's 'intercollated' awards, which enable medical and dental students to carry out a research project leading to a BSc.
Barbara Rashbass, director of the foundation, says that charitable bodies are entitled to decide how to allocate their funds and that unsuccessful applicants are free to apply for support from other medical research charities, none of which has similar restrictions. Last week, the Physiological Society decided that it would not pursue the matter at the present time, and would accept the foundation's argument.

The Wolfson Foundation spends about $£ 17$ million a year on medical research (compared with a total of about $£ 400$ million spent by the other charities). The guidelines are widely believed to reflect the personal antipathy towards animal experiments of the foundation's chairman, Lord Wolfson.

The foundation does support research using animal tissue. And it has also provided financial backing for research into alternatives to the use of animals. Thus it has supported research in the department of human morphology at the University of Nottingham into the possible use of the fluorescein leakage test as an alternative to the Draize rabbit eye irritancy test to measure the potentially harmful effects of cosmetics.

Although there is little criticism of the foundation's decision to support such research, other medical charities argue that its explicit exclusion of research on animals may encourage other smaller research-funding bodies to take a similar stand, a move that could make life increasingly difficult for medical researchers. The larger charities - which have recently formed a group known as Research for Health Charities to respond to criticism of the use of animals in experiments - also feel that Wolfson's stand undermines their attempts to establish a united front.

\section{Glowing report may not avert closure of Dutch primate centre}

Munich. Europe's leading primate centre, which pioneered bone-marrow transplantation in the 1960s and which now supplies animals for AIDS research, faces a financial crisis that could lead to closure. Although an independent report on its activities has recommended continued support for the centre at Rijswijk in the Netherlands, many fear that the Dutch government will adhere to an austerity programme that provides no money to operate the centre.

Cuts last year in the Dutch health budget were passed on to the national applied research organization (TNO), whose own grant is being halved by 1994. In response, TNO told the primate centre and its associated radiobiology and immunology research institute ITRI to make good a deficit of around DF13.7 million (US\$2 million). The pros-

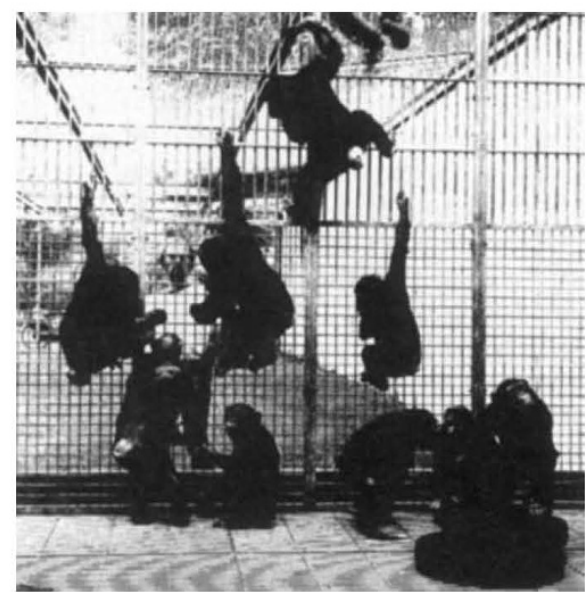

These primates face uncertain futures. pect that the primate centre could be closed raised such a storm of protest that the government agreed to delay a decision until after the completion of a report on the centre's performance by the Royal Netherlands Academy of Arts and Sciences.

The international investigating committee, chaired by Jon van Rood, professor of immunohaematology in Leiden, has strongly recommended that the centre and its research facilities should be preserved despite the cost. It judged the centre, which carries out work on AIDS, infectious disease and transplant research, to be a worldclass laboratory and says that it offers unique facilities to researchers in Europe such as a rhesus colony for which the microbiological status is known and typed for major histocompatibility complex, essential for transplantation studies and infectious disease research. It also has the only breeding colony in Europe for chimpanzees.

An estimated 5,500 primates were used in Europe last year, according to the report, mostly by the pharmaceutical industry. The primate centre received requests for 300 macaques and 14 chimpanzees, many of which could not be supplied because of a policy that it should be primarily a supplier for TNO institutes.

The report proposes a new structure for the centre, which it says has been underused as a TNO institute. It recommends that it should be taken over by the academy because of its focus on basic research and that it should at the same time establish links with a university. It also recommends that the European Communities (EC) adopt the centre as a 'Grande Installation' under their Human Capital and Mobility scheme, coordinating its activities with those of the other two European primate breeding and research units, in Göttingen, Germany and Strasbourg, France. The EC has shown interest in the idea, which could provide the centre with DFll.8 million per year.

Transferring the centre to the academy, however, will not solve the fundamental problem of tightening government budgets. The academy has already said that it will consider the proposition only if the government provides continuing support to operate and maintain the facility, which the report estimates would require DF17 million (US\$4 million) a year. If that is done, according to the report, the centre could attract at least DF110 million a year from national and EC grants, industrial contracts and the sale of animals.

But the government is unlikely to want to foot the bill. TNO vice-president Arthur Rörsch says that the government is pleased that the centre is valued so highly but that, "against a background of budget cuts, with health budgets particularly under fire, it is not really easy to be optimistic". Minister of education and science Jo Ritzen has promised an answer this month.

If the government decides against underwriting the venture, then the centre must decide the fate of hundreds of primates. Some of the chimpanzees could be transferred to zoos, but the chimpanzees infected with AIDS must be cared for in special facilities until their deaths.

Alison Abbott 